\title{
SERVICE TRADE AND NON-OIL EXPORT IN NIGERIA
}

\author{
Mmaduabuchukwu Mkpado, Researcher \\ Department of Agricultural Economics and Extension, Federal University Oye-Ekiti, Nigeria \\ E-mail: mmaduabuchukwu.mkpado@fuoye.edu.ng, mkpado@gmail.com
}

\begin{abstract}
The paper was set to examine the relationship between different aspects of service trade and non oil export in Nigeria as well as assess the impact of capacity development on value of service trade and the implications for improving value of non oil export in Nigeria. Secondary data 1980 to 2010 were used. Data were analysed using descriptive statistics, correlation analysis and regression analysis. Results show that total service trade value in Nigeria has increased from $\$ 1126.59$ million in 1980 to $\$ 3076.19$ million in 2010. Significant correlations existed between the total value of service trade and all the types of service trade except with other service trade value. Road network, government (domestic) capital expenditure on services, agricultural credit and domestic service GDP positively determine exportable services. Recommendations include improvement of service GDP and agricultural credit/loan facilities.
\end{abstract}

\section{KEYWORDS}

Exportable services; Road network; Government expenditure; Agricultural credit.

Services constitute one of the key sectors providing significant contribution to economic growth and a country's competitiveness including Nigeria and African as a whole (Table 1). Banking, insurance and finance, tourism, retail and food and beverages, media and entertainment, education and health, and airline industry are some of the sub-sectors in the services sector. The list also includes electricity and water supply as well as good road networks. A country's domestic capacity to provide these services will not only improve welfare of her citizens but also in the long run became a set of assets for attraction of foreign exchange. Table 1 is a breakdown of subsectors contribution to Nigerian Gross Domestic Product (GDP) in 2010. It showed that the service sector is the second largest contributor to the country's GDP. Nigeria Government established the Federal Service Commission (SERVICOM) in 2005 to promote service in the country. Thus, the Government knew the potentials of using the services sub sector to create wealth and alleviate poverty.

Today, tourism is a fast growing foreign exchange earner for countries that have developed or developing the sub sector and its associated services. Kaur (2011) aptly noted that due to technological progress, since 1980s, international trade in services has been increasing rapidly. It has now accounted for twenty per cent of globe trade. Globally, the share of primary sector and secondary sector has been declining while the share of service sector is growing rapidly. Through the internet and ecommerce, many communications and information processing activities have opened new opportunities for cross border service trade, which has strengthened the importance of international service trade.

Table 1. Sector contribution to GDP in Nigeria

\begin{tabular}{|c|c|}
\hline ORDER GDP BREAKDOWN FOR NIGERIA & $\%$ to the GDP 2010 \\
\hline Agriculture & 40.84 \\
\hline Wholesale and Retail Contributed & 18.70 \\
\hline Crude Petroleum \& Natural Gas Contributed & 15.85 \\
\hline Tele Communication /Postal Services & 4.56 \\
\hline Manufacturing & 4.16 \\
\hline Finance \& Insurance & 3.57 \\
\hline Building \& Construction & 2.00 \\
\hline Real Estate & 1.74 \\
\hline Business \& Other Services & 0.90 \\
\hline Hotel and Restaurant & 0.50 \\
\hline Solid Minerals & 0.34 \\
\hline Others & 6.83 \\
\hline
\end{tabular}

Source: CBN Annual Report 2011 
Trade can play a crucial role in the development of service sectors in Nigeria. Services offer new dynamic opportunities for exports, especially for land-locked countries, while opening up to imports of services and foreign direct investment is a key mechanism to increase competition and drive greater efficiency in the provision of services in the domestic economy. Trade policy especially liberalization is a very important variable in determining the nature of competition in domestic services sectors. Countries that place restrictions on foreign services providers may limit access to the most efficient suppliers and the best technologies and, in turn, deny producers and consumers throughout the economy access to low cost services or to the types of services that are most appropriate for their needs. Similarly restrictions in overseas markets can act as a constraint on the development of services exports for which the country has a comparative advantage (World Bank, 2010). Despite the importance of services and trade in services, few countries in Africa have defined a trade strategy for them. In ECOWAS for instance the ECOWAS common external tariffs are in accordance with trade liberalisation policy (Achike, Mkpado and Arene, 2008). The ongoing liberalisation of trade is a favourable conduction for generating exportable services.

Trade in services offers new opportunities for export diversification. The Nigerian Government through its export promotion council has been encouraging the diversification of the domestic foreign exchange earners. Often services are overlooked as a source of export diversification and discussions and trade policies are inappropriately focused on manufactures. Considerable scope remains to expand traditional sectors such as tourism. In addition, the telecommunications revolution is making new opportunities available for export, growth and employment. The fastest growing top 100 company in Kenya in 2009 is an exporter of services. It is estimated that each job in such export oriented services sectors supports an additional 3 or 4 jobs in the wider economy (World Bank, 2010). Exports of services appear to be of particular importance for land-locked countries for whom opportunities to diversify into the export of manufactures are more limited by the high costs of transporting goods. Indeed, over the past 10 years exports of services from non-oil exporting land-locked countries in Africa have increased at a rate more than 3 times faster than their exports of goods (Brenton, et al 2010).

Components of exportable services include:

- Transport covers all transport services that are provided by residents of one economy for those of another and that involve the carriage of passengers, the movement of goods (freight), rentals (charters) of carriers with crew, and related supporting and auxiliary services. All modes of transport are considered including sea, air, space, rail, road, inland waterway, and pipelines, as are other supporting and auxiliary services (such as storage and warehousing).

- Travel covers primarily the goods and services acquired from an economy by travellers during visits of less than one year to that economy. The goods and services are purchased by, or on behalf of, the traveller or provided, without a quid pro quo (that is, are provided as a gift), for the traveller to use or give away. The transportation of travellers within the economies that they are visiting, where such transportation is provided by carriers not resident in the particular economy being visited, as well as the international carriage of travellers are excluded; both are covered in passenger services under transport. Also excluded are goods purchased by a traveller for resale in the traveller's own economy or in any other economy. Travel is divided in two subcomponents: business travel and personal travel.

- Other services comprise external transactions not covered under transport or travel, specifically: communications services, construction services, insurance services, financial services, computer and information services, royalties and licence fees, other business services, personal, cultural and recreational services, and government services (Permani, 2008).

Problem statement. World Bank (2010) has noted that Africa has not been able to increase its share of global services trade over the past two decades. Nevertheless, the available case study and anecdotal evidence suggests that there are considerable opportunities for the expansion of trade in services to the global market and between African countries from both the growth of existing flows and from increasing the range of sectors in which trade in services takes place. 
Trade in services can improve not only the performance of the service sector but also the whole economy (Arnold et al., 2007 Francois et al., 2007). Despite the increasing importance of services trade in global economy, there has been limited research on service trade (Kaur, 2011). Unfortunately, there is lack of awareness in many developing countries including Nigeria about the key role of services trade in development, and this leads to a lack of coherence in their policies. Lack of coherence deter potential investors and impede trade despite the absence of impediments to market access. Research is yet to fill such gap.

The objectives were to (a) examining performance of Nigerian exportable services (b) examine the relationship between different aspects of service trade and non oil export in Nigeria, (c) assess the impact of capacity development on value of exportable services and (d) draw lessons for achieving higher service trade in Nigeria.

Conceptual framework. The components of this exportable services include: travel which includes goods and services acquired from an economy by non-resident travellers during visits shorter than one year; transport, which covers all transport services that involve carriage of passengers, movement of goods, freight, rentals et c.; memo item, which covers all service categories except government services; and others, which include all services except transportation and travel.

Stern (2002) noted that Leamer (1974) identifies three groups of explanatory variables, all of which he applies to trade in goods. The three groups of variables are resource variables, development variables and resistance variables. These same classifications were used by Stern (2002) to distinguish between the possible determinants of trade in services in South Africa. The three categories of variable were namely: (a) Resource variables include Human capital, Physical capital, Natural resources, Technology; (b) Development variables such as or Economic development indicator in terms of GDP, size with respect to producer services namely financial and insurance services, Export orientation which can be known as export diversification as well as (d) Resistance variables such as protection, geography and language.

In another development, Kaur (2011) employed a gravity model which strength is on size of GDP to examine determinants of export services of USA with its Asian Partners using panel data. However, the study included variables such as openness, corruption index and similarities among countries. While all variables were significant at Restricted/Pooled Estimation, Fixed Effects Estimation and Random Effects Estimation; openness was not significant at Random Effects Estimation (in this study trade liberalisation started in 1986 and the date frame was $1980-2010$ thus liberalisation as a variable is skewed already and modelling it in the data even as a dummy can lead to bias.

In this study one of the challenges/constraints to choice of model and variables is the data frame of the dependent variable (exportable service performance) which available data started from 1980. Thus only factors which variables can have good representation approximating normal distribution were selected. Trade openness was excluded because it already a major component of the dependent variable.

Thus it is specified that total exportable services is a function of some explanatory variables:

Where:

$$
\text { TES }=f(G E C, \text { ACGSF }, \text { SGDP, Road, ACU, FDI , EPC) }+ \text { e.....(1) }
$$

- Total Exportable services (TES) is measured in US dollars,

- Government expenditure on services (GEC) is measured in naira,

- ACGSF is volume of agricultural credit measured in naira,

- Service GDP (SGDP) is the value of GDP produced by service sector,

- Federal road net work is the length road networks in $\mathrm{Km}$,

- Average capacity utilization (ACU) is the average capacity utilization of electricity in mega watts,

- FDI in trading and business services is measured in US Dollar,

- Export Promotion Council (EPC) is a dummy variable used to denote structural change resulting in liberalization of administration of EPC; zero denotes prior to liberalization (before 1992) and one denotes liberalised era (after 1992). 


\section{RESULTS AND DISCUSSIONS}

Trend in performance of exportable services in Nigeria. Table 2 is an illustration of performance of exportable services in Nigeria. From 1980 to 2010 the greater proportion of export service performance occurred from 2005 up wards. This is an indication that the post Structural Adjustment Period (SAP) period has experienced more exportable services.

Table 2. Trend of Exportable services, Service GDP and non oil Export values in Nigeria*

\begin{tabular}{|c|c|c|c|c|c|c|c|}
\hline Year & $\begin{array}{c}\text { Total } \\
\text { services } \\
\text { (Millions \$) }\end{array}$ & $\begin{array}{l}\text { Transport } \\
\text { services } \\
\text { (Millions \$) }\end{array}$ & $\begin{array}{c}\text { Travel } \\
\text { services } \\
\text { (Millions \$) }\end{array}$ & $\begin{array}{c}\text { Other } \\
\text { services } \\
\text { (Millions \$) }\end{array}$ & $\begin{array}{c}\text { Memo item: } \\
\text { Commercial } \\
\text { services } \\
\text { (Millions \$) }\end{array}$ & $\begin{array}{c}\text { service GDP } \\
\text { in (Millions } \\
\text { N) }\end{array}$ & $\begin{array}{l}\text { VAL NON } \\
\text { Oil EXPORT } \\
\text { (Millions N) }\end{array}$ \\
\hline 1980 & $\begin{array}{c}1126.59 \\
(9.817478)\end{array}$ & $\begin{array}{c}911.334 \\
(17.37722)\end{array}$ & $\begin{array}{c}67.6688 \\
(5.260716)\end{array}$ & $\begin{array}{c}147.587 \\
(2.984794)\end{array}$ & $\begin{array}{c}1126.59 \\
(10.5829)\end{array}$ & $\begin{array}{c}4,748.06 \\
(0.346211)\end{array}$ & $\begin{array}{c}554.4 \\
(0.079694)\end{array}$ \\
\hline $\begin{array}{l}1980- \\
1984\end{array}$ & $\begin{array}{l}679.0492 \\
(5.91746)\end{array}$ & $\begin{array}{c}454.831 \\
(8.672667)\end{array}$ & $\begin{array}{l}107.9065 \\
(8.38888)\end{array}$ & $\begin{array}{c}116.3116 \\
(2.352282)\end{array}$ & $\begin{array}{c}679.0492 \\
(6.378816)\end{array}$ & $\begin{array}{l}16864.058 \\
(1.229665)\end{array}$ & $\begin{array}{c}329.82 \\
(0.047411)\end{array}$ \\
\hline $\begin{array}{l}1985- \\
1989\end{array}$ & $\begin{array}{c}341.0652 \\
(2.972155)\end{array}$ & $\begin{array}{l}97.41716 \\
(1.85754)\end{array}$ & $\begin{array}{c}69.93458 \\
(5.436863)\end{array}$ & $\begin{array}{c}173.7136 \\
(3.513178)\end{array}$ & $\begin{array}{l}341.0652 \\
(3.20388)\end{array}$ & $\begin{array}{l}20125.904 \\
(1.467507)\end{array}$ & $\begin{array}{c}1782.6 \\
(0.256244)\end{array}$ \\
\hline $\begin{array}{l}1990- \\
1994\end{array}$ & $\begin{array}{c}887.505 \\
(7.734012)\end{array}$ & $\begin{array}{l}108.1693 \\
(2.06256)\end{array}$ & $\begin{array}{c}27.23927 \\
(2.117639)\end{array}$ & $\begin{array}{c}752.0964 \\
(15.21037)\end{array}$ & $\begin{array}{c}887.505 \\
(8.336997)\end{array}$ & $\begin{array}{l}29480.126 \\
(2.149582)\end{array}$ & $\begin{array}{c}4501 \\
(0.647007)\end{array}$ \\
\hline $\begin{array}{l}1995- \\
1999\end{array}$ & $\begin{array}{c}797.9906 \\
(6.953954)\end{array}$ & $\begin{array}{c}99.62676 \\
(1.899672)\end{array}$ & $\begin{array}{c}41.5225 \\
(3.228047)\end{array}$ & $\begin{array}{c}656.8414 \\
(13.28394)\end{array}$ & $\begin{array}{c}797.9906 \\
(7.496121)\end{array}$ & $\begin{array}{c}35271.3 \\
(2.571854)\end{array}$ & $\begin{array}{c}25830 \\
(3.712995)\end{array}$ \\
\hline $\begin{array}{l}2000- \\
2004\end{array}$ & $\begin{array}{c}2563.81 \\
(22.34189)\end{array}$ & $\begin{array}{c}351.4354 \\
(6.701131)\end{array}$ & $\begin{array}{c}76.3108 \\
(5.932563)\end{array}$ & $\begin{array}{c}2136.064 \\
(43.19968)\end{array}$ & $\begin{array}{c}2563.81 \\
(24.08378)\end{array}$ & $\begin{array}{l}60959.552 \\
(4.444946)\end{array}$ & $\begin{array}{c}71129.8284 \\
(10.22473)\end{array}$ \\
\hline $\begin{array}{l}2005- \\
2009\end{array}$ & $\begin{array}{c}2003.152 \\
(17.45613)\end{array}$ & $\begin{array}{l}1260.255 \\
(24.0304)\end{array}$ & $\begin{array}{c}324.5456 \\
(25.23086)\end{array}$ & $\begin{array}{c}418.3514 \\
(8.460724)\end{array}$ & $\begin{array}{c}1636.051 \\
(15.36865)\end{array}$ & $\begin{array}{l}103985.967 \\
(7.582275)\end{array}$ & $\begin{array}{c}195160.074 \\
(28.05375)\end{array}$ \\
\hline 2010 & $\begin{array}{c}3076.19 \\
(26.80694)\end{array}$ & $\begin{array}{c}1961.35 \\
(37.3988)\end{array}$ & $\begin{array}{c}571.176 \\
(44.40443)\end{array}$ & $\begin{array}{c}543.664 \\
(10.99504)\end{array}$ & $\begin{array}{c}2613.321 \\
(24.54887)\end{array}$ & $\begin{array}{c}1100000 \\
(80.20796)\end{array}$ & $\begin{array}{l}396,377.2 \\
(56.97818)\end{array}$ \\
\hline Total & $\begin{array}{c}11475.35 \\
(100)\end{array}$ & $\begin{array}{c}5244.419 \\
(100)\end{array}$ & $\begin{array}{c}1286.304 \\
(100)\end{array}$ & $\begin{array}{c}4944.629 \\
(100)\end{array}$ & $\begin{array}{c}10645.38 \\
(100)\end{array}$ & $\begin{array}{c}1371435 \\
(100)\end{array}$ & $\begin{array}{c}695664.9 \\
(100)\end{array}$ \\
\hline
\end{tabular}

* Values in parenthesis are percentages. Computed from UNTACD DATA base

A closer look at the trend reveals that it is ' $u$ ' shaped curve indicating a decrease from the value in 1980 to 1989 and then increased till 2010. A similar trend characterised the values of transport and memo services, while the value for travel fluctuated from 1980 to 1984 the similar trend holds from 1985 to 2010 . Why the SAP era did witnessed a decrease in export of service trade? It may be that the era was a pro export of goods regimes with restricted imports. This can reduce degree of openness which has been documented to have a positive relationship with export of service (World Bank, 2010). It is not surprising that service GDP trend mirrored the trend of performance of services because the total service GDP is a derived function which components can be a reflection export service performance. It is interesting to note that trend in value of non oil export tend to follow the trend in service trade. This has implication for this study.

The value of non oil export decreased from N554.4 in 1980 to N329.82 million between A 1980 and 1984 but increased to 1782.6 million from 1985 to 1989 . This could have been influenced by adoption of Structural Adjustment Programme. It latter decreased to 4501 million from 1990 to 1994 but increased to N25830 million from 1995 to 19999 and increased to N71129.8284 million between 2000 and 2004, further increased to N195160.074 between 2005 and 2009, and to N396,377.2 million in 2010. The consecutive increases in export of non oil products can be attributed to the changes made in the Nigeria Export promotion Council (NEPC) to improve its performance especially in dealing with the private sector. The NEPC Amendment Decree No.64 of 1992 was promulgated to enhance the performance of the Council by minimizing bureaucratic bottlenecks and increasing its autonomy in dealing with members of the organised private sector. 
The apparent synergy between service trade and non oil export was tested using Pearson correlation coefficient and significant relationships were recorded. It implied that factors which affect export service will likely affect non oil export.

Table 3. Correlates of exportable services with non oil export in Nigeria

\begin{tabular}{|c|c|c|c|c|}
\hline Variable 1 & Variable 2 & $\begin{array}{l}\text { Pearson } \\
\text { Correlation }\end{array}$ & $P$ value & Significant level \\
\hline Value of Total services & Value of non oil export & $.707^{x-1}$ & 0.000 & 0.01 level (2-tailed). \\
\hline Value of Transport & Value of non oil export & $.807^{*}$ & 0.000 & 0.01 level (2-tailed). \\
\hline Value of Travel & Value of non oil export & .858 & 0.000 & 0.01 level (2-tailed). \\
\hline Value of Other services & Value of non oil export & .130 & .487 & Not significant (2-tailed). \\
\hline $\begin{array}{l}\text { Value of Memo item: } \\
\text { Commercial services }\end{array}$ & Value of non oil export & $.598^{\star *}$ & .000 & 0.01 level (2-tailed) \\
\hline
\end{tabular}

$N=31$.

Source: Author's computation.

Selected variables that can affect exportable services performance. Besides service GDP other variables which can affect exportable services include government economic services capital expenditure, agricultural credit guarantee scheme fund (ACGSF) FDI in business and trade service, road network and average capacity utilization of non oil sector. The trends of these variables are presented in Table 4. Generally, the magnitudes of variables have been on the increase since the post SAP era.

Table 4. Trend of Selected variables that can affect exportable services performance

\begin{tabular}{|c|c|c|c|c|c|}
\hline Year & $\begin{array}{l}\text { Government ECONOMIC } \\
\text { SERVICES CAP EXP (N) }\end{array}$ & $\begin{array}{l}\text { ACGSF } \\
\text { (N) }\end{array}$ & $\begin{array}{c}\text { FDI IN TRADE } \\
\text { Business Services } \\
(\$)\end{array}$ & Road km & $\begin{array}{c}\text { average capacity } \\
\text { utilization of non oil } \\
\text { sector }\end{array}$ \\
\hline 1980 & $\begin{array}{c}5,981.1 \\
(57.79533)\end{array}$ & $\begin{array}{c}30,945.0 \\
(714.1571)\end{array}$ & $\begin{array}{c}693.2 \\
(1.214744)\end{array}$ & $\begin{array}{c}8186.4 \\
(1.807037)\end{array}$ & $\begin{array}{c}70.1 \\
(21.02706)\end{array}$ \\
\hline $\begin{array}{l}1980- \\
1984\end{array}$ & $\begin{array}{c}679.0492 \\
(6.561648)\end{array}$ & $\begin{array}{c}454.831 \\
(10.49671)\end{array}$ & $\begin{array}{c}1,568.3 \\
(29.35904)\end{array}$ & $\begin{array}{c}19736.16 \\
(4.356489)\end{array}$ & $\begin{array}{c}59.94 \\
(17.97948)\end{array}$ \\
\hline $\begin{array}{l}1985- \\
1989\end{array}$ & $\begin{array}{c}341.0652 \\
(3.295711)\end{array}$ & $\begin{array}{l}97.41716 \\
(2.24822)\end{array}$ & $\begin{array}{c}2,262.5 \\
(32.71425)\end{array}$ & $\begin{array}{c}11829.64 \\
(2.611232)\end{array}$ & $\begin{array}{c}40.74 \\
(12.22029)\end{array}$ \\
\hline $\begin{array}{l}1990- \\
1994\end{array}$ & $\begin{array}{c}887.505 \\
(8.575955)\end{array}$ & $\begin{array}{c}108.1693 \\
(2.496361)\end{array}$ & $\begin{array}{c}2,112.2 \\
(8.332497)\end{array}$ & $\begin{array}{l}30472.07 \\
(6.726296)\end{array}$ & $\begin{array}{c}37.6 \\
(11.27842)\end{array}$ \\
\hline $\begin{array}{l}1995- \\
1999\end{array}$ & $\begin{array}{c}797.9906 \\
(7.710978)\end{array}$ & $\begin{array}{l}99.62676 \\
(2.299213)\end{array}$ & $\begin{array}{c}3,030.1 \\
(4.477462)\end{array}$ & $\begin{array}{c}31990.11 \\
(7.061382)\end{array}$ & $\begin{array}{c}31.83 \\
(9.547663)\end{array}$ \\
\hline $\begin{array}{l}2000- \\
2004\end{array}$ & $\begin{array}{c}2563.81 \\
(24.77408)\end{array}$ & $\begin{array}{l}351.4354 \\
(8.110522)\end{array}$ & $\begin{array}{c}4,929.6 \\
(7.649834)\end{array}$ & $\begin{array}{l}33044.34 \\
(7.294089)\end{array}$ & $\begin{array}{c}49.18 \\
(14.75193)\end{array}$ \\
\hline $\begin{array}{l}2005- \\
2009\end{array}$ & $\begin{array}{c}2003.152 \\
(19.35644)\end{array}$ & $\begin{array}{l}1260.255 \\
(29.08451)\end{array}$ & $\begin{array}{c}9,374.3 \\
(8.188725)\end{array}$ & $\begin{array}{l}27976.84 \\
(6.175508)\end{array}$ & $\begin{array}{c}54.092 \\
(16.22533)\end{array}$ \\
\hline 2010 & $\begin{array}{c}3076.19 \\
(29.7252)\end{array}$ & $\begin{array}{c}1961.35 \\
(45.26457)\end{array}$ & $\begin{array}{c}33,095.3 \\
(9.276177)\end{array}$ & $\begin{array}{c}297979.84 \\
(65.775)\end{array}$ & $\begin{array}{c}60 \\
(17.99748)\end{array}$ \\
\hline Total & $\begin{array}{c}10,348.76 \\
(100)\end{array}$ & $\begin{array}{c}4,333.08 \\
(100)\end{array}$ & $\begin{array}{c}57,065.5 \\
(100)\end{array}$ & $\begin{array}{c}453,029.00 \\
(100)\end{array}$ & $\begin{array}{c}333.38 \\
(100)\end{array}$ \\
\hline
\end{tabular}

Values in parenthesis are percentages.

Source: Authors computation from CBN publications and UNCTAD data base.

Modelling of Determinants of Export Service in Nigeria. In order to produce an acceptable result, normality test was conducted, the time series properties were examined and cointegrating test was also conducted and finally dynamic approach was used to estimate the model. Almost all the variables in the model are normally distributed. This showed that the emerging result will be acceptable, provided the Durbin Watson statistics is within acceptable limit. 
Table 5. Normality Test

\begin{tabular}{|c|c|c|}
\hline Variable & Chi-square value & Remarks \\
\hline DLTota Export Service & $3.9229[0.1407]$ & normally distributed \\
\hline DDLGOV. Expenditure on services & $25.424[0.0000]^{\star \star}$ & normally distributed \\
\hline DDLACGSF & $6.5624[0.0376]^{\star}$ & normally distributed \\
\hline DDL service GDP & $1.0185[0.6009]$ & Not normally distributed \\
\hline DDL Federal road net work in $\mathrm{Km}$ & $33.378[0.0000]^{\star \star}$ & normally distributed \\
\hline $\mathrm{DDL}$ average capacity utilization & $15.212[0.0005]^{\star \star}$ & normally distributed \\
\hline $\mathrm{DDL} \%$ FDI in trading and business services & $6.3422[0.0420]^{*}$ & normally distributed \\
\hline Export Promotion Council & $70.466[0.0000]^{\star \star}$ & normally distributed \\
\hline
\end{tabular}

$D=1^{\text {st }}$ difference, $D D=2^{\text {nd }}$ difference, $L=\log$

Source: Authors computation

The time series properties were examined. The results showed that the variables were stationary within the limits of statistical procedures.

Table 6. Unit Root Test

\begin{tabular}{|c|c|}
\hline Variable & ADF-Value \\
\hline DLTotal Exportable services & $-3.9344^{*} 1(0)$ \\
\hline DDLGOV. Expenditure on services & $-7.2927^{\star \star} 1(0)$ \\
\hline DDL ACGSF & $-6.9636^{\star \star} 1(0)$ \\
\hline DDL Service GDP & $-7.3346^{\star *} 1(0)$ \\
\hline DDL Federal road net work in Km & $-8.2251^{\star \star} 1(0)$ \\
\hline DDL Average capacity utilization & $-7.0652^{\star \star} 1(0)$ \\
\hline DDL FDI in Trading and Business Services & $-10.597^{\star \star} 1(0)$ \\
\hline
\end{tabular}

$D=1^{\text {st }}$ difference, $D D=2^{\text {nd }}$ difference, $L=L o g$

Critical values: $5 \%=-3.712 ; 1 \%=-4.619$; Constant and Trend included

The variables were stationary at different level of differencing. Which is an indication that there is no long run relationship between them, also efforts were made to examine the same issue using E-views and the result showed no cointegrating vectors (Table 7).

Table 7. Unrestricted Cointegration Rank Test (Trace)

\begin{tabular}{|c|c|c|c|c|c|}
\hline $\begin{array}{c}\text { Hypothesized } \\
\text { No. of CE(s) }\end{array}$ & Eigenvalue & $\begin{array}{c}\text { Trace } \\
\text { Statistic }\end{array}$ & $\begin{array}{c}0.05 \\
\text { Critical Value }\end{array}$ & Prob. & Remarks \\
\hline None & 0.671244 & 94522.75 & NA & 0.5000 & Not significant \\
\hline At most 1 & 0.484543 & 35287.50 & NA & 0.5000 & Not significant \\
\hline
\end{tabular}

Trace test indicates no cointegration at the 0.05 level * denotes rejection of the hypothesis at the 0.05 level

**MacKinnon-Haug-Michelis (1999) p-values

Source: Authors computation

Table 8. Dynamic modelling of determinants of export service in Nigeria*

\begin{tabular}{|c|c|c|c|c|c|}
\hline Variable & Coefficient & Std.Error & t-value & t-prob & PartRý \\
\hline Constant & 0.15347 & 0.091812 & 1.672 & 0.1228 & 0.2026 \\
\hline DDroad k & $1.7711 \mathrm{e}-005$ & $7.0897 \mathrm{e}-006$ & 2.498 & 0.0296 & 0.3620 \\
\hline DDLGOVEXp 1 & 0.38953 & 0.11217 & 3.473 & 0.0052 & 0.5230 \\
\hline DDLACGSF & 0.51568 & 0.25024 & 2.061 & 0.0638 & 0.2785 \\
\hline DDL\%FDI trade & -0.21811 & 0.15950 & -1.367 & 0.1966 & 0.1348 \\
\hline exp prom co & -0.034957 & 0.12757 & -0.274 & 0.7891 & 0.0068 \\
\hline DDL avecap & -1.0020 & 0.84871 & -1.181 & 0.2627 & 0.1125 \\
\hline DDL service & 1.6092 & 1.2008 & 1.340 & 0.2072 & 0.1404 \\
\hline
\end{tabular}

${ }^{*} R y ́=0.675835 F(7,11)=3.2762[0.0388] a ̊=0.29422 D W=1.97 R S S=0.9522181351$ for 8 variables and 19 observations. Source: Authors' computation 
The results of modelling the determinants of export service in Nigeria is acceptable because of its significant regression parameters (see table 5) such F-ratio (3.2762), low variance of the estimate $(\stackrel{a}{=}=0.29422)$, high coefficient of determination (0.675835) and acceptable Dobbin Watson statistics (1.97).

The significant explanatory variables are road network, government (domestic) capital expenditure on services, volume of agricultural credit guarantee fund, proportion of FDI inflow in trade and business and domestic service GDP. Road network is essential to convey goods and services as well as people from one place to another. Thus foreigners especially tourists need to move from place to place within the country. The result indicated that increasing road network will lead to increase in greater service in Nigeria.

Government (domestic) capital expenditure on services such as transport and communication, tourism and education positively influenced exportable services in Nigeria. It is possible that Nigerian Government efforts to catch-up with trend in information and communication technology and provision of some basic tourist facilities can boost export service performance. Thus the result is an indication that increase in government capital expenditure on social and economic services will lead to higher export of service.

Volume of agricultural credit guarantee fund was positively related to the service. Many of Nigerian service include agricultural products. Besides agriculture is a source of food materials for populace and even the travellers especially tourists. Thus increase in investment in agricultural credit has a positive relationship with exportable services.

FDI inflow in trade and business as expected had positive relationship with exportable services. Also domestic service GDP had positive relationship with the exportable services. The actual services rendered have the potential of attracting exportable services.

Variable that were not significant are average capacity utilization of non oil sector and export promotion council. Average capacity utilization of the non oil sector although surprisingly not significant can increase exportable services. If the sector production is of high quality, travellers will be willing to obtain such goods and services. The non significant of this available indicates that Nigerian non oil production sector need to improve in the quality of their output to attract foreigners.

The Nigerian Export Promotion Council (NEPC) was established through the promulgation of the Nigerian Export Promotion Decree No. 26 of 1976 and formally inaugurated in March, 1977. This act was amended by Decree No. 72 of 1979 and further amended by the Nigerian Export Promotion Decree No. 41 of 1988 and complimented by the Export (Incentives and Miscellaneous Provisions) Decree No. 18 of 1986. Furthermore, the Nigerian Export Promotion Council Amendment Decree No. 64 of 1992 was promulgated to enhance the performance of the Council by minimizing bureaucratic bottlenecks and increasing autonomy in dealing with members of the Organised Private sector. The Council has a governing Board drawn from both the Public and the Private sectors.

Other variables which literature has shown can increase export performance include trade openness as well as information and communication technology. World Bank (2010) noted that a range of empirical studies have shown that openness to trade in services, such as telecommunications and finance, is associated with greater efficiency and faster growth. Also Harsh (2012) noted that preferential trade agreements especially multilateral agreements has can improve trade in services.

\section{CONCLUSION}

Nigeria needs to increase performance in exportable services because of its many advantages. Service trade especially export offers new opportunities for export diversification which can be used to create new job opportunities, wealth and poverty reduction. It can offer a way to sustain trade Liberalization and regulation of services sectors because improved performance in exportable services will motivate a country to invest more in the service sub sector as well as its regulation for better economic and social gains. Exportable services are mechanisms for increasing competition in services as countries will thrive to increase their exportable services. Greater efficiency and faster economic growth can be achieved by 
developing trade in services as the example from Kenya has shown. It can help to increase economic partnership agreements among Africans and with other nations. African countries can pursue to support coordinated trade and regulatory reform in services together with unilateral, regional and multilateral reforms. The tempo will can be sustained with service trade.

The paper has examined the relationship between different aspects of service trade and non oil export in Nigeria as well as assessed the impact of certain variables on value of service trade and highlighted the implications for improving service trade and non oil export in Nigeria. For Nigeria to attract higher service trade it is recommended that she engagement in economic partnership agreements. This will enable her to increase her trading partners. Also, develop domestic capacity to attract FDI in trade and business services, increase agricultural credit, domestic service GDP and road networks since they impact positively on value of exportable services which have strong correlation with export value of non oil products.

\section{REFERENCES}

[1] Arnold, J., Javorcik B. S., and Mattoo A. (2007), "The Productivity Effects of Services Liberalization: Evidence from the Czech Republic." World Bank Policy Research Working Paper No. 4730.

[2] Brenton, P., Dihel, N., Hinkle, L. and Strychacz N. (2010), Africa's Trade in Services and the Opportunities and Risks of Economic Partnership Agreements Africa Trade Policy Notes Note \#6 September, http://siteresources.worldbank.org/INTAFRREGTOPTRADE/Resources/EPAPolicyNo teREVISED.pdf

[3] CBN (2011), Central Bank of Nigeria Annual Report 2011 Abuja.

[4] Deardorf, A. V. (1994), "Testing Trade Theories and Predicting Trade Flows," in Jones R.W and P. B. Kenen (eds.) (1994) Handbook of International Economics, Amsterdam, North Holland Publishing Co.

[5] Francois, J., B. Hoekman and J. Woerz (2007), "Does Gravity Apply to Intangibles? Measuring Barriers to Trade in Services" Paper presented at the CEPII-OECD Workshop Recent Developments in International Trade in Services, Paris, November.

[6] Harsh H.G. (2012), Preferential and Regional Service Agreements: The way forward for developing countries? A paper presented at the $7^{\text {th }}$ TRAPCA annual conference held at Arusha, Tanzania. $22^{\text {nd }}-23$ Nov.

[7] Kaur S. (2011), "Determinants of Export Services of USA with its Asian Partners: A Panel Data Analysis" Eurasian Journal of Business and Economics Vol. 4 No 8 pp 101-117.

[8] Leamer, E.E. (1974), "The Commodity Composition of International Trade in Manufactures: An Empirical Analysis”, Oxford Economic Papers Vol. 24: pp 350-374.

[9] Permani, R. (2008), Trade in Services: How is Indonesia's performance? http://indonesianlabourstudies.wordpress.com/2011/06/08/trade-in-services-how-isindonesias-performance/

[10] Stern, M. (2002), Predicting South African Trade in Services Trade and Industrial Policy Strategies Annual Forum at Glenburn Lodge, Muldersdrift http://www.tips.org.za/iles/564.pdf

[11] Saez, S. and Goswam, A. G. (2010), Uncovering Developing Countries' Performance in Trade in Services. The world Bank Economic Premise, November, No.39 http://www.worldbank/EP39 servicetrade.pdf

[12] World Bank (2010) Africa's Trade in Services and Economic Partnership Agreements. Report No.:55747-AFR, July 20, Africa Region www.AfricaTradeinServicesandEPAsNEW.pdf 